ISSN: 2302-8556

E-Jurnal Akuntansi Universitas Udayana

Vol.22.1. Januari (2018): 521-543

DOI: https://doi.org/10.24843/EJA.2018.v22.i01.p20

\title{
Pengaruh Partisipasi Anggaran Terhadap Budgetary Slack Dengan Self Esteem Sebagai Variabel Moderasi
}

\author{
Made Dwi Mardhiana ${ }^{1}$ \\ ${ }^{1}$ Fakultas Ekonomi dan Bisnis Universitas Udayana (Unud), Bali, Indonesia \\ e-mail: dwimardhiana@yahoo.com / Telp: +6281 286127917
}

\begin{abstract}
ABSTRAK
Budgetary slack merupakan ketidakseimbangan antara potensi anggaran sesungguhnya dengan anggaran yang disusun. Partisipasi anggaran sering dihubungkan dengan permasalahan budgetary slack. Self Esteem dikatakan merupakan unsur yang dapat mengurangi gejala budgetary slack.Tujuan peneltian ini adalah untuk mengetahui bukti empiris pengaruh partisipasi anggaran terhadap budgetary slack dengan self esteem sebagai variabel moderasi. Acuan teori yang digunakan adalah teori keagenan dan teori kontinjensi. Penelitian ini dilakukan pada 6 Satuan Kerja Perangkat Daerah (SKPD) penghasil Pendapatan Asli Daerah (PAD) Pemerintah Daerah Provinsi Bali. Sampel yang digunakan adalah pejabat Eselon II, III, dan IV. Metode yang digunakan dalam penentuan sampel adalah purposive sampling dan diperoleh 56 pejabat sebagai sampel penelitian. Teknik yang digunakan untuk mengumpulkan data adalah kuesioner. Alat uji yang digunakan pada pengujian hipotesis pertama adalah analisis regresi linier sederhana dan uji nilai selisih mutlak pada pengujian hipotesis kedua. Hasil pengujian hipotesis pertama dengan analisis regresi linier berganda ditemukan bahwa variabel partisipasi anggaran memiliki pengaruh positif terhadap budgetary slack. Hasil pengujian hipotesis kedua dengan uji nilai selisih mutlak ditemukan bahwa self esteem dinyatakan sebagai variabel moderasi yang memperlemah hubungan partisipasi anggaran terhadap budgetary slack. Saran yang dapat diberikan adalah mengurangi tingkat partisipasi pejabat dengan hanya melibatkan pejabat yang memiliki self esteem yang tinggi agar dapat mengurangi budgetary slack.

Kata Kunci: partisipasi anggaran, budgetary slack, self esteem
\end{abstract}

\begin{abstract}
Budgetary slack is an imbalance between actual budget potential and budget being drafted. Budgetary participation is often associated with budgetary slack problems. Self Esteem said to be an element that reduce the symptoms of budgetary slack. The purpose of this study is to prove the empirical evidence of the effect of budgetary participation on budgetary slack with self esteem as a moderation variable. The theoretical references are agency theory and contingency theory. This research was conducted on 6 Regional Work Unit Organization (SKPD) as revenue center of Bali Province Government. The samples are Echelon II, III, and IV officials. The method used in determining the sample is purposive sampling and obtained 56 officials as sample. The technique used to collect data is questionnaire. The test used in the first hypothesis testing is a simple linear regression analysis and test of absolute difference value in testing the second hypothesis. The results of the first hypothesis testing with multiple linear regression analysis found that the budget participation has a positive effect on budgetary slack. The result of the second hypothesis testing with the test of absolute difference value found that the self esteem is as a moderation variable that weakens the relationship of budget participation to budgetary slack. The suggestion that can be given is to reduce the level of official participation by only involving officials who have high self esteem in order to reduce budgetary slack. Keywords: budgeting participation, budgetary slack, self esteem
\end{abstract}




\section{PENDAHULUAN}

Pemerintah daerah menyusun anggaran untuk melaksanakan kegiatan dan program yang direncanakan setiap tahunnya. Anggaran adalah unsur yang penting di dalam sebuah instansi pemerintahan. Fungsi anggaran salah satunya adalah sebagai alat ukur kinerja organisasi, dapat dilihat dari penyerapan atau realisasi dari anggaran tersebut. Anggaran pemerintah daerah digunakan sebagai perencanaan keuangan daerah dalam melakukan kegiatan dan program daerah, dimana satu pihak memperkirakan biaya untuk pelaksanaan kegiatan dan program daerah, dan pihak lain memperkirakan pendapatan yang dapat diterima daerah guna menutupi biaya yang dikeluarkan.

Sistem penganggaran telah mengalami beberapa perubahan pada sector pemerintahan sejak berlakunya Undang-Undang Nomor 17 Tahun 2003 tentang keuangan negara, dimana perubahan dalam penganggaran yang dimaksud adalah perubahan yang semula adalah traditional budgeting menjadi performance based budgeting. Penerapan sistem ini diharapkan dapat menimbulkan peningkatkan kinerja dari agen. Agen yang dimaksud merupakan Satuan Kerja Perangkat Daerah (SKPD) dimana peranannya merupakan pihak yang menggunakan anggaran, dan sebagai penyusun anggaran yang kemudian disahkan oleh pihak kepala daerah diikuti dengan pengesahan oleh Dewan Perwakilan Rakyat Daerah (DPRD) sebagai pihak prinsipal. Pendekatan yang digunakan dalam penyusunan APBD adalah bottom-up approach. Pendekatan 
ISSN: 2302-8556

E-Jurnal Akuntansi Universitas Udayana

Vol.22.1. Januari (2018): 521-543

ini digunakan agar pihak agen sebagai pengguna anggaran ikut berpartisipasi dalam menyusun anggaran.

Partisipasi dalam penganggaran merupakan sebuah proses penyusunan anggaran dimana terdapat kumpulan individu yang ikut serta dalam proses penganggaran dan memiliki efek terhadap target sebuah anggaran. (Brownell, 1982). Harapan dari penerapan penyusunan anggaran secara partisipatif adalah agar anggaran yang disusun dapat terlaksana dengan baik setara dengan kemampuan yang dimiliki pengguna anggaran.

Dibalik harapan atas partisipasi dalam penyusunan anggaran, terdapat kelemahan yang dapat terjadi apabila penyusunan anggaran yang melibatkan agen. Seorang agen yang ikut serta dalam proses penganggaran dapat menyebabkan pelaksanaan anggaran tidak berjalan sesuai kapasitas agen, hal ini disebut dengan budgetary slack. Schiff dan Lewin (1970) mengatakan budgetary slack didefinisikan sebagai ketidakseimbangan antara potensi anggaran sesungguhnya dengan anggaran yang disusun. Menurut Young (1985) budgetary slack dilakukan oleh agen dengan cara memperkecil kemampuan maksimal dari kinerjanya ketika agen berkesempatan dalam penentuan standar kerjanya. Budgetary slack adalah adanya ketidakseimbangan pada penyusunan anggaran dimana terdapat penurunan anggaran pendapatan dan peningkatan belanja yang dianggarkan.

Berhubungan dengan budgetary slack, ada beberapa faktor yang mendorong agen untuk melakukan budgetary slack. Salah satunya adalah 
Undang-Undang Nomor 28 Tahun 2009 tentang pajak dan retribusi daerah yang menyatakan organisasi pemerintah yang terlibat langsung dalam penagihan pajak maupun retribusi akan mendapatkan bonus apabila kinerja organisasi tersebut mencapai target tertentu, hal ini diduga menjadi motivasi agen dalam melakukan budgetary slack. Satuan Kerja Perangkat Daerah (SKPD) sebagai pihak penyusun anggaran diduga melakukan manipulasi anggaran pendapatan menjadi lebih rendah agar mudah dicapai, sehingga seolah-olah kinerja SKPD tersebut terlihat baik.

Tabel 1.

Data Realisasi Anggaran Pendapatan Pemerintah Provinsi Bali Tahun 2012-2016 (dalam jutaan)

\begin{tabular}{cccc}
\hline Tahun & Anggaran (Rp) & Realisasi (Rp) & \% \\
\hline $\mathbf{2 0 1 2}$ & 3.398 .346 .627 & 3.633 .133 .585 & 107 \\
$\mathbf{2 0 1 3}$ & 3.763 .503 .621 & 4.109 .377 .804 & 109 \\
$\mathbf{2 0 1 4}$ & 4.231 .297 .026 & 4.577 .678 .390 & 108 \\
$\mathbf{2 0 1 5}$ & 4.900 .892 .105 & 4.967 .903 .231 & 101 \\
$\mathbf{2 0 1 6}$ & 5.218 .112 .635 & 5.249 .017 .441 & 100,5 \\
\hline Sumber: & BPKAD Provinsi Bali (data diolah, 2017)
\end{tabular}

Tabel 1 menunjukan bahwa pendapatan selalu terealisasi lebih tinggi dari pada anggarannya, sehingga diduga ada indikasi terjadinya budgetary slack. Terlihat juga pada data realisasi tersebut, indikasi budgetary slack mengalami penurunan setiap tahunnya, sehingga diduga terdapat faktor lain yang dapat mengurangi gejala budgetary slack.

Partisipasi dalam penyusunan anggaran seringkali dihubungkan dengan terjadinya budgetary slack, karena jika dilihat dari perspektif teori keagenan yang mengatakan bahwa agen memiliki hubungan kontraktual dengan prinsipal, 
ISSN: 2302-8556

E-Jurnal Akuntansi Universitas Udayana

Vol.22.1. Januari (2018): 521-543

dimana pihak prinsipal berperan sebagai pemberi perintah atau pedoman kepada agen guna melaksanakan kepentingan pihak prinsipal. Hubungan keagenan dapat menimbulkan konflik kepentingan, karena agen memiliki perbedaan keinginan dengan prinsipal, sehingga agen tidak selalu berperilaku sesuai keinginan atau harapan dari prinsipal. Hal ini dapat menyebabkan terjadinya asimetri informasi atau terjadi kesalahpahaman antara pihak agen dan prinsipal (Darlis, 2002).

Penelitian terdahulu oleh, Elmassri dan Harris (2011), Ajibolade dan Akinniyi (2013), Hassabelnaby, et al (2013), Pratama (2013), Thien (2014), Kramer dan Hartmann (2014), Gallani (2015), dan Harvey (2015) menemukan hasil yaitu partisipasi anggaran memiliki pengaruh positif pada budgetary slack, yang berarti jika tingkat partisipasi anggaran tinggi, maka akan meningkatkan budgetary slack. Namun, pada penelitian dari Husain (2011), Lavarda, et al (2013), Sinaga (2013), Su dan Ni (2013), Mahadewi (2014), Pamungkas (2014), dan Baerdemaeker, et al (2015), ditemukan hasil penelitian yang lain yaitu, partisipasi anggaran memiliki pengaruh negatif pada budgetary slack, hasil atau temuan tersebut berarti apabila tingkat partisipasi dalam proses penganggaran yang tinggi akan mengurangi terjadinya budgetary slack. Uraian diatas dan acuan pada teori keagenan mendasari perumusan hipotesis berikut: $\mathrm{H}_{1}$ : Partisipasi anggaran berpengaruh positif terhadap budgetary slack.

Fahrianta dan Ghozali (2002) mengatakan apabila penelitian-penelitian terdahulu memiliki perbedaan hasil, maka kemungkinan terdapat hal lain pada 
faktor partisipasi anggaran dan budgetary slack yang dapat terlibat dalam hubungan kedua unsur tersebut. Perbedaan temuan pada penelitian terdahulu dapat diselaraskan dengan menerapkan pendekatan kontinjensi (Govindarajan, 1986). Pendekatan kontinjensi merupakan sebuah rancangan yang mengatakan bahwa sebuah sistem kontrol tidak dapat diterapkan pada seluruh organisasi dan sebuah sistem yang benar harus mengamati adanya faktor lain di luar sistem yang kemungkinan dapat terlibat pada sebuah organisasi (Otley, 1980).

Budgetary slack sering dihubungkan dengan masalah pada organisasi atau faktor perilaku individu pada saat menyusun anggaran yang dapat menyebabkan terjadinya budgetary slack. Self esteem merupakan faktor yang dapat mempengaruhi perilaku seseorang, sehingga self esteem diduga merupakan faktor yang dapat mempengaruhi hubungan partisipasi anggaran pada budgetary slack, karena self esteem merupakan evaluasi diri seseorang dimana seorang individu yakin akan kapasitas yang dimiliki. Dalam hubungannya dengan budgetary slack, seseorang dengan self esteem yang tinggi akan merasa bahwa dirinya berpengaruh dalam tahap penyusunan anggaran, dan berusaha sebaik mungkin untuk menghindari kesalahan, sehingga dapat menurunkan tingkat budgetary slack.

Penelitian yang dilakukan oleh Resen (2014), Novia (2015), dan Azcarlo (2016) ditemukan bahwa variabel self esteem memperlemah hubungan antara partisipasi anggaran terhadap budgetary slack, hasil tersebut memiliki arti apabila semakin tinggi self esteem seseorang dalam penyusunan anggaran, 
ISSN: 2302-8556

E-Jurnal Akuntansi Universitas Udayana

Vol.22.1. Januari (2018): 521-543

maka terjadinya budgetary slack cenderung semakin rendah. Teori kontinjensi dan penelitian sebelumnya mendasari perumusan hipotesis berikut:

$\mathrm{H}_{2}$ : Self esteem memperlemah hubungan antara partisipasi anggaran dengan budgetary slack.

\section{METODE PENELITIAN}

Terdapat tiga variabel yang digunakan pada model regresi yaitu, partisipasi anggaran (X) sebagai variabel independen, budgetary slack (Y) sebagai variabel dependen, dan self esteem (Z) sebagai variabel moderasi. Gambaran hubungan antar variabel dapat dilihat pada Gambar 1.

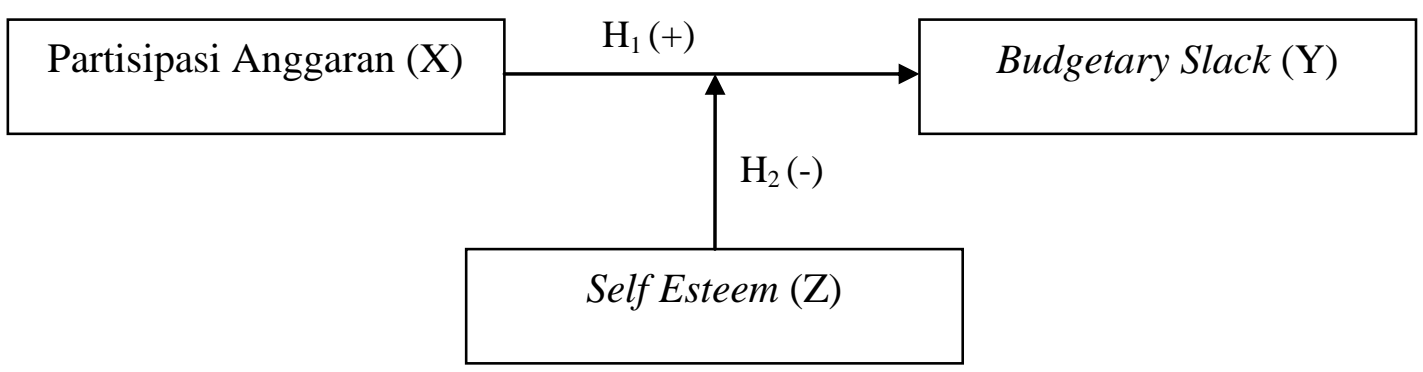

\section{Gambar 1. Desain Penelitian}

Partisipasi dalam menyusun anggaran merupakan keikutsertaan atau keterlibatan agen untuk menyusun anggaran secara bersama-sama. Hal ini dilakukan karena agen lebih mengetahui situasi dan kondisi secara keseluruhan pada lingkungannya. Variabel partisipasi anggaran diukur menggunakan kuesioner dengan jumlah pernyataan sejumlah 6 butir dan menggunakan skala likert 6 poin. Adapun indikator sebagai dasar perumusan pernyataan, yaitu: 1) Kontribusi dalam proses penganggaran. 2) Keterlibatan dalam proses 
penganggaran. 3) Revisi anggaran oleh atasan. 4) Usulan kepada atasan. 5) Penyelesaian akhir. 6) Pendapat dari Atasan.

Budgetary slack merupakan ketidakseimbangan antara potensi anggaran sesungguhnya dengan anggaran yang disusun, dengan mengecilkan kapabilitas produktifnya ketika diberi kesempatan untuk menentukan standar kerjanya. Variabel budgetary slack diukur menggunakan kuesioner dengan jumlah pernyataan sejumlah 5 butir dan menggunakan skala likert 6 poin. Indikator yang digunakan dalam kuesioner tersebut, yaitu: 1) Standar anggaran. 2) Pencapaian anggaran. 3) Keketatan Anggaran. 4) Tuntutan anggaran. 5) Sasaran anggaran.

Self Esteem merupakan evaluasi diri seseorang, dimana seorang individu percaya dengan kemampuan yang dimiliki, sehingga dapat mengetahui apa yang harus dikerjakan dalam sebuah organisasi. Variabel self esteem diukur menggunakan kuesioner dengan pernyataan sejumlah 10 butir dan diukur menggunakan skala likert 6 poin. Adapun indikator dalam pernyataan yang dimaksud, yaitu: 1) Tingkat keseriusan seseorang. 2) Tingkat kepercayaan yang diterima oleh seorang individu dari orang lain. 3) Tingkat peranan individu dalam organisasi. 4) Tingkat kemampuan seorang individu melakukan perubahan positif. 5) Tingkat seorang individu dalam menghargai diri sendiri. 6) Tingkat kemampuan individu dalam membantu orang lain dalam organisasi. 7) Tingkat keyakinan bahwa individu dapat diandalkan dalam sebuah organisasi. 8) Tingkat kemampuan individu dalam bekerja sama. 9) Tingkat 
ISSN: 2302-8556

E-Jurnal Akuntansi Universitas Udayana

Vol.22.1. Januari (2018): 521-543

keyakinan individu pada diri sendiri. 10) Tingkat efisiensi pada seorang individu.

Purposive sampling akan digunakan pada penelitian ini sebagai metode penentuan sampel. Adapun syarat penentuan sampel, yaitu: 1) Sampel merupakan pejabat Eselon II, III, dan IV yang ikut serta pada proses penganggaran pendapatan, 2) Sampel telah menduduki jabatan minimal selama 2 tahun dan telah berpartisipasi dalam penyusunan anggaran pendapatan serta merasakan dampak dari realisasi anggaran pendapatan. Sampel yang digunakan berjumlah 70, terdiri dari pejabat struktural Eselon II, II, dan IV.

Tabel 2. Lokasi dan Sampel Penelitian

\begin{tabular}{|c|c|c|c|c|c|}
\hline \multirow[b]{2}{*}{ No } & \multirow[b]{2}{*}{ Nama SKPD } & \multicolumn{4}{|c|}{ Jumlah Pejabat Struktural } \\
\hline & & $\begin{array}{c}\text { Eselon } \\
\text { II }\end{array}$ & $\begin{array}{l}\text { Eselon } \\
\text { III }\end{array}$ & $\begin{array}{c}\text { Eselon } \\
\text { IV }\end{array}$ & Jumlah \\
\hline $\mathbf{1}$ & Badan Pendapatan Daerah & 1 & 3 & 9 & 13 \\
\hline 2 & $\begin{array}{l}\text { Badan Pengelola Keuangan Dan Aset } \\
\text { Daerah }\end{array}$ & 1 & 3 & 7 & 11 \\
\hline 3 & Dinas Kebudayaan & 1 & 5 & 10 & 16 \\
\hline 4 & Dinas Kelautan Dan Perikanan & 1 & 3 & 8 & 12 \\
\hline 5 & $\begin{array}{l}\text { Dinas Pekerjaan Umum Dan Penataan } \\
\text { Ruang }\end{array}$ & 1 & 3 & 6 & 10 \\
\hline 6 & Dinas Perhubungan & 1 & 2 & 5 & 8 \\
\hline & Jumlah & 6 & 19 & 45 & 70 \\
\hline
\end{tabular}

Sumber: BKD Provinsi Bali (data diolah, 2017)

Terdapat dua alat pengujian hipotesis pada penelitian ini, alat pengujian pertama adalah analisis regresi linier sederhana untuk pengujian hipotesis pertama, kemudian alat pengujian kedua adalah uji nilai selisih mutlak yang digunakan untuk menguji hipotesis kedua, alasan dari penggunaan uji nilai selisih mutlak dalam menguji interaksi partisipasi anggaran dengan self esteem 
adalah untuk menghindari peluang terjadinya multikolinearitas pada model penelitian.

Pengujian pertama dengan analisis regresi linier sederhana yang digunakan untuk membuktikan kemampuan variabel partisipasi anggaran dalam mempengaruhi budgetary slack, pengujian kedua menggunakan uji nilai selisih mutlak yang digunakan untuk mengetahui moderasi self esteem pada pengaruh partisipasi anggaran terhadap budgetary slack. Seluruh pengujian dilakukan menggunakan software Statistical Package for the Social Science (SPSS) V.24.

\section{HASIL DAN PEMBAHASAN}

Data pada Tabel 3 diperoleh dari pengumpulan kuesioner yang telah diisi oleh responden berdasarkan jabatan struktural Eselon II, III, dan IV pada Satuan Kerja Perangkat Daerah (SKPD) penghasil Pendapatan Asli Daerah (PAD) Pemerintah Provinsi Bali yang ikut serta dalam penyusunan anggaran pendapatan. Jumlah kuesioner yang disebar dan tingkat pengembalian dapat dilihat pada Tabel 3 .

Tabel 3. Rangkuman Penyebaran dan Pengambilan Kuesioner

\begin{tabular}{lc}
\hline \multicolumn{1}{c}{ Keterangan } & Jumlah \\
\hline Tersebar & 70 \\
Kembali & 66 \\
Tidak kembali & 4 \\
Tidak sesuai kriteria & 10 \\
Sesuai kriteria dan digunakan & 56 \\
\hline Usable respon rate $=56 / 70 \times 100 \%=80 \%$ & \\
Sumber: data diolah, 2017 &
\end{tabular}


ISSN: 2302-8556

E-Jurnal Akuntansi Universitas Udayana

Vol.22.1. Januari (2018): 521-543

Bedasarkan Tabel 3, kuesioner yang direspon sebanyak 66 buah kuesioner dari keseluruhan kuesioner yang telah disebar, kuesioner yang tidak direspon sebanyak 4 buah kuesioner karena disebabkan oleh keterbatasan waktu yang dimiliki oleh para pejabat Eselon II, III, dan IV. 10 kuesioner tidak dapat digunakan karena jawaban yang diisi responden pada demografi pengalaman dalam proses penganggaran tidak mencapai 2 tahun. Total kuesioner yang dipakai sebagai data penelitian berjumlah 56 buah kuesioner atau sebesar $80 \%$ dari seluruh kuesioner yang disebar.

Sebuah instrumen penelitian yang baik dan dapat digunakan dalam sebuah penelitian adalah instrumen yang valid dan reliable. Pada penelitian ini, seluruh instrumen penelitian telah melewati pengujian instrumen yang menggunakan pearson correlation pada pengujian validitas instrumen dan cronbach's alpha pada pengujian reliabilitas instrumen, seluruh instrumen penelitian dinyatakan valid dan reliable.

Tabel 4.

Statistik Deskriptif

\begin{tabular}{lcccc}
\hline \multicolumn{1}{c}{ Variabel } & N & Terendah & Tertinggi & Rata-Rata \\
\hline Partisipasi Anggaran & 56 & 21.00 & 31.00 & 26.6429 \\
Budgetary Slack & 56 & 20.00 & 29.00 & 25.4821 \\
Self Esteem & 56 & 27.00 & 49.00 & 42.3036 \\
\hline Sumber: data diolah, 2017 & & &
\end{tabular}

Berdasarkan Tabel 4, dapat diketahui bahwa rata-rata pejabat Eselon II, III, dan IV di lingkungan SKPD penghasil PAD Pemerintah Provinsi Bali memiliki tingkat partisipasi anggaran yang cenderung tinggi pada nilai rata-rata 
26,6. Tingkat budgetary slack juga cenderung tinggi pada nilai rata-rata 25,4. Tingkat self esteem yang dimiliki pejabat Eselon II, III, dan IV cenderung tinggi dengan nilai rata-rata 42,3 .

Tahapan awal sebelum melakukan pengujian sebuah model yaitu, uji asumsi klasik yang merupakan syarat melakukan analisis regresi terdiri dari, uji normalitas yang menggunakan Kolmogorov-Smirnov residual test. Uji kedua yaitu, uji multikolinearitas yang menggunakan angka tingkat toleransi dan Variance Inflation Factor (VIF). Kemudian yang terakhir adalah pengujian heteroskedastisitas dengan menggunakan metode glejser.

Seluruh uji asumsi klasik yang telah disebutkan telah diuji dan model dinyatakan layak untuk dilanjutkan pada analisis regresi. Terdapat tiga bagian pada pengujian hipotesis, yaitu uji adjusted $R^{2}$, uji F, dan uji t. Hipotesis akan diuji menggunakan analisis regresi linear sederhana yang bertujuan untuk menguji hipotesis pertama, yaitu untuk mengetahu pengaruh partisipasi anggaran terhadap budgetary slack. Kemudian pengujian hipotesis kedua diuji menggunakan uji nilai selisih mutlak untuk mengetahui moderasi self esteem dalam hubungan antara partisipasi anggaran dengan budgetary slack. Hasil pengujian hipotesis pertama dan kedua dapat dilihat pada Tabel 10 dan 11.

\section{Tabel 5.}

\section{Hasil Analisis Regresi Sederhana (Model 1)}

\begin{tabular}{cccc}
\hline Variabel & Beta & t Value & Sig. \\
\hline PA $(\mathrm{X})$ & 0,769 & 12,375 & 0,000 \\
\hline \multicolumn{4}{c}{ Adjusted $\mathrm{R}^{2}=0,734$} \\
Sumber: data diolah, 2017
\end{tabular}

Sumber: data diolah, 2017 
Tabel 6.

Hasil Pengujian Nilai Selisih Mutlak (Model 2)

\begin{tabular}{lccc}
\hline \multicolumn{1}{c}{ Variabel } & Beta & t Value & Sig. \\
\hline ZPA (X) & 1,491 & 8,599 & 0,000 \\
ZSE (Z) & $-1,096$ & $-4,717$ & 0,000 \\
$\mid$ ZPA - ZSE & $-0,737$ & $-3,370$ & 0,001 \\
\hline & Adjusted $\mathrm{R}^{2}=0,807$ & & $\mathrm{~F}=0,000$ \\
\hline
\end{tabular}

Sumber: data diolah, 2017

Berdasarkan hasil analisis regresi diatas, disusun persamaan regresi sebagai berikut:

Persamaan Model 1:

$$
\begin{aligned}
\mathrm{Y} & =\mathrm{a}+{ }_{\mathrm{b} 1} \mathrm{PA}+\mathrm{e} \ldots \ldots \ldots \\
& =4,989+0,769+\mathrm{e}
\end{aligned}
$$

Persamaan Model 2 :

$$
\begin{aligned}
\mathrm{Y} & =\mathrm{a}+{ }_{\mathrm{b} 1} \mathrm{ZPA}+{ }_{\mathrm{b} 2} \mathrm{ZSE}+{ }_{\mathrm{b} 3}|\mathrm{ZPA}-\mathrm{ZSE}|+\mathrm{e} . . \\
& =26,442+1,491-1,096-0,737+\mathrm{e}
\end{aligned}
$$

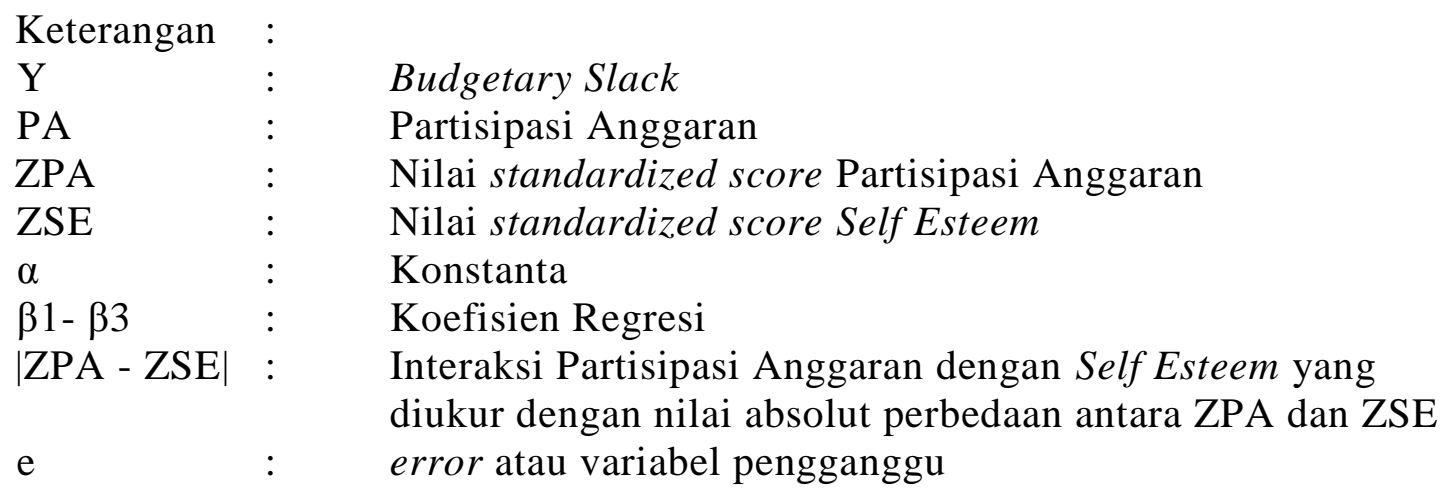

Bagian pertama dalam pengujian hipotesis adalah adjusted $R^{2}$ yang berfungsi sebagai alat untuk mengetahui kapasitas variabel independen dalam menerangkan variabel dependen. Hasil Adjusted $R^{2}$ model pertama pada Tabel 5 bernilai 0,734 . Hal ini berarti variabel partisipasi anggaran mampu menerangkan 
variabel budgetary slack sebesar 73,4 persen, nilai sisa 26,6 persen diterangkan melalui variabel yang terdapat di luar model. Adjusted $\mathrm{R}^{2}$ model kedua pada Tabel 6 bernilai 0,807, yang berarti variabel partisipasi anggaran, self esteem, dan hubungan partisipasi anggaran dengan self esteem mampu menerangkan variabel budgetary slack sebesar 80,7 persen, nilai sisa 19,3 persen diterangkan melalui variabel yang terdapat di luar model.

Bagian kedua dalam pengujian hipotesis adalah uji $\mathrm{F}$ dilakukan agar dapat mengetahui kelayakan atau good and fit suatu model peneltian. Hasil Uji F pada model pertama dan kedua menunjukan nilai $0,000<0,05$. Hasil tersebut memiliki arti bahwa uji $\mathrm{F}$ pada seluruh model penelitian yang digunakan dinyatakan signifikan seperti yang terdapat pada Tabel 5 dan 6. Berdasarkan hasil uji F diatas, dapat ditarik kesimpulan bahwa seluruh model pada penelitian ini layak digunakan atau fit.

Bagian terakhir dalam pengujian hipotesis adalah uji t yang bertujuan untuk mengetahui bagaimana kemampuan variabel independen dalam mempengaruhi variabel dependen. Hasil uji hipotesis pertama menunjukan nilai koefisien beta $\left(b_{1}\right)=0,769$, nilai beta menunjukan arah yang positif yang berarti apabila partisipasi anggaran mengalami peningkatan sebesar satu poin, akan terjadi peningkatan budgetary slack sebesar 0,769. Hasil tersebut berarti bahwa partisipasi anggaran memiliki pengaruh positif terhadap budgetary slack. Kemudian pada kolom signifikansi menunjukan angka $0,000<0,05$, yang artinya variabel partisipasi anggaran mempunyai pengaruh signifikan pada 
ISSN: 2302-8556

E-Jurnal Akuntansi Universitas Udayana

Vol.22.1. Januari (2018): 521-543

variabel budgetary slack sehingga $\mathrm{H}_{1}$ diterima. Berdasarkan uraian hasil analisis, dapat dikatakan bahwa partisipasi anggaran mempunyai pengaruh atau hubungan yang positif pada budgetary slack.

Hasil tersebut menerangkan bahwa tingginya tingkat partisipasi pejabat Eselon II, III, dan IV dalam proses penganggaran pendapatan dapat meningkatkan terjadinya budgetary slack. Perilaku menyimpang seperti ini salah satunya dapat ditimbulkan karena pejabat yang ikut serta pada proses penyusunan anggaran pendapatan ingin dengan mudah memperoleh insentif atas pencapaian anggaran pendapatan.

Partisipasi anggaran menjadi salah satu dari banyak unsur yang dapat menciptakan budgetary slack, agen yang ikut serta dalam sebuah penyusunan anggaran akan menciptakan anggaran dengan tingkat kesulitan rendah agar dapat dengan mudah mencapai target anggaran, sehingga proses penyusunan anggaran dengan keikutsertaan kumpulan individu dapat menciptakan budgetary slack. Hal ini dapat disebabkan karena agen ingin dengan mudah memperoleh insentif atas tercapainya target anggaran, selain itu agen ingin menjaga citra baik di mata pihak prinsipal, sehingga dengan cara menyusun anggaran dengan tingkat kesulitan rendah, agen dapat dengan mudah merealisasikan anggaran, sehingga agen dapat mencerminkan kinerja yang baik di mata pihak prinsipal.

Kepentingan pimpinan organisasi dapat pula menjadi faktor lain yang dapat menyebabkan terjadinya budgetary slack, karena dengan mencerminkan kinerja organisasi yang baik, pimpinan organisasi dapat dinilai baik kinerjanya 
oleh pihak prinsipal. Hal tersebut menjadi perilaku yang menyimpang dari tujuan atau pedoman dari prinsipal, karena harapan dari diselenggarakannya penganggaran secara partisipatif dimaksudkan agar kinerja agen menjadi maksimal, namun adapun peluang bahwa harapan tersebut dapat terjadi sebaliknya.

Perilaku manipulatif seperti ini dapat menyebabkan penurunan kinerja dari agen. Apabila hal tersebut terjadi berkelanjutan pada organisasi sektor publik dimana tujuan dari organisasi tersebut adalah melayani dan mengutamakan kepentingan masyarakat, maka dapat terjadi penurunan kualitas pelayanan masyarakat pula.

Hasil analisis penelitian ini didukung oleh penelitian sebelumnya yakni, Elmassri dan Harris (2011), Ajibolade dan Akinniyi (2013), Hassabelnaby, et al (2013), Pratama (2013), Thien (2014), Kramer dan Hartmann (2014), Gallani (2015), dan Harvey (2015) yang mendapatkan temuan bahwa partisipasi anggaran memiliki pengaruh yang positif pada budgetary slack. Hasil pengujian uji hipotesis ini didukung dengan teori keagenan, dimana terdapat unsur berupa konflik kepentingan antara agen dengan prinsipal. Hal ini dapat menyebabkan seorang agen berperilaku menyimpang terhadap pedoman, perintah atau harapan dari pihak prinsipal.

Hasil uji hipotesis kedua menunjukan nilai koefisien beta $\left(b_{3}\right)=-0,737$, nilai beta menunjukan arah yang negatif yang berarti apabila self esteem mengalami peningkatan sebesar satu poin, maka dapat menurunkan tingkat 
ISSN: 2302-8556

E-Jurnal Akuntansi Universitas Udayana

Vol.22.1. Januari (2018): 521-543

budgetary slack sebesar -0,737. Hasil tersebut berarti bahwa variabel interaksi self esteem dengan partisipasi anggaran memliki pengaruh negatif terhadap budgetary slack, atau dengan kata lain self esteem memperlemah pengaruh antara partisipasi anggaran dengan budgetary slack. Pada kolom signifikansi menunjukan angka $0,001<0,05$ yang berarti signifikan sehingga keputusan yang diambil adalah menerima $\mathrm{H}_{2}$, dapat dikatakan bahwa self esteem merupakan variabel moderasi.

Berdasarkan hasil uji nilai selisih mutlak tersebut, dapat dikatakan bahwa variabel self esteem mampu memoderasi dan memperlemah pengaruh variabel partisipasi anggaran dalam hubungannya dengan variabel budgetary slack. Hasil analisis tersebut menjelaskan bahwa self esteem yang tinggi pada proses penyusunan anggaran akan menurunkan tingkat terjadinya budgetary slack, karena seseorang dengan self esteem yang tinggi akan merasa bahwa dirinya berpengaruh dalam tahap penyusunan anggaran, dan berusaha sebaik mungkin untuk menghindari kesalahan.

Self esteem merupakan evaluasi diri yang dibuat dan dijaga oleh individu tersebut. Self esteem akan membuat seseorang dapat mengkaji kembali keadaan dirinya yang kemudian akan menimbulkan rasa menghargai diri sendiri, sehingga tercipta suatu perilaku yang menyetujui atau sebaliknya dan mencerminkan rasa percaya akan kemampuannya. Dalam hubungannya dengan budgetary slack, seseorang dengan self esteem yang tinggi dapat mengurangi tingkat budgetary slack, hal ini dapat terjadi karena dalam tahap penyusunan 
anggaran seseorang dengan self esteem tinggi akan berusaha sebaik mungkin untuk menghindari kesalahan-kesalahan.

Berdasarkan penjelasan diatas, kemampuan self esteem dalam memperlemah hubungan antara partisipasi anggaran dengan budgetary slack terbukti, karena seseorang yang ikut serta dalam proses penganggaran memiliki self esteem tinggi akan merasa dirinya penting, dan memiliki pengaruh di dalam organisasi, maka timbul rasa percaya diri bahwa apa yang dilakukannya akan menghasilkan kinerja yang maksimal, selain itu seseorang dengan self esteem yang tinggi dapat meningkatkan perasaan atau kesadaran untuk bekerja sama dengan rekan kerjanya, sehingga dapat terjadi peningkatan koordinasi dalam melakukan pekerjaan yang dapat terlaksana dengan benar. Namun, sebaliknya apabila seseorang memiliki self esteem yang rendah, maka dapat terjadi kesalahan atau ketidaksesuaian dalam koordinasi dalam kerja sama, hal ini dapat terjadi karena seorang dengan self esteem rendah akan memandang dirinya merasa tidak mampu melakukan pekerjaan yang dilakukan pula oleh seseorang dengan self esteem tinggi, selain itu seseorang dengan self esteem rendah akan kesulitan dalam melakukan pekerjaan yang membutuhkan koordinasi tinggi. Berdasarkan uraian diatas dapat dikatakan bahwa variabel self esteem adalah salah satu dari banyak variabel yang dapat menurunkan kecenderungan menciptakan budgetary slack dalam proses penyusunan anggaran apabila tingkat self esteem yang dimiliki seorang individu tinggi. 
ISSN: 2302-8556

E-Jurnal Akuntansi Universitas Udayana

Vol.22.1. Januari (2018): 521-543

Hasil analisis penelitian ini didukung oleh penelitian sebelumnya yaitu, Resen (2014), Novia (2015) dan Azcarlo (2016) yang menyimpulkan bahwa self esteem mampu mengurangi budgetary slack. Hasil ini membuktikan kebenaran teori kontinjensi, dimana terdapat faktor tertentu yaitu self esteem yang dapat mempengaruhi hubungan partisipasi anggaran terhadap budgetary slack.

\section{SIMPULAN}

Penelitian ini tidak terlepas dari berbagai keterbatasan, seperti penyebaran kuesioner pada beberapa SKPD masih memiliki kendala dalam prosedur perizinan dan pengisian kuesioner, untuk peneliti selanjutnya disarankan agar responden yang dituju dapat melakukan pengisian kuesioner yang disebarkan. Selain itu, Metode pengumpulan data penelitian ini menggunakan metode survei dengan menggunakan kuesioner sehingga dapat menyebabkan kemungkinan terjadinya perbedaan persepsi antara responden dengan peneliti yang berkaitan dengan pernyataan yang terdapat dalam kuesioner.

Berdasarkan hasil dan keterbatasan penelitian mengenai pengaruh partisipasi anggaran terhadap budgetary slack dengan self esteem sebagai variabel moderasi di SKPD penghasil PAD Pemerintah Provinsi Bali dapat disimpulkan bahwa partisipasi anggaran berpengaruh positif terhadap budgetary slack. Semakin tinggi tingkat partisipasi individu dalam proses penganggaran khususnya pendapatan, maka dapat meningkatkan terjadinya budgetary slack. Hal ini dapat terjadi karena agen ingin dengan mudah memperoleh insentif atas 
tercapainya anggaran pendapatan, selain itu adapula kepentingan SKPD penghasil PAD agar dapat menjaga nama baik dimata pihak prinsipal dengan mencerminkan kinerja yang baik, sehingga agen menciptakan anggaran pendapatan yang mudah dicapai.

Self esteem mampu memoderasi dan memperlemah pengaruh partisipasi anggaran terhadap budgetary slack. Hal ini dapat terjadi karena Seseorang dengan self esteem yang tinggi termotivasi untuk melakukan pekerjaannya dengan baik untuk menjaga konsistensi hasil evaluasi dirinya agar tetap baik. Sehingga seseorang dengan self esteem yang tinggi dapat mengurangi tingkat budgetary slack, karena dalam tahap penyusunan anggaran seseorang dengan self esteem tinggi akan berusaha sebaik mungkin untuk menghindari kesalahankesalahan yang kemungkinan dapat terjadi, selain itu, seseorang dengan self esteem tinggi dapat berkoordinasi dengan baik dalam melakukan pekerjaannya.

Berdasarkan kesimpulan yang didapat, peneliti selanjutnya diharapkan dapat memutakhirkan intrumen yang akan digunakan dalam penelitian selanjutnya dengan cara menyesuaikan indikator penelitian dengan keadaan lokasi penelitian guna menghindari kesalahan persepsi antara responden dengan peneliti. Selain itu, berdasarkan nilai Adjusted $\mathrm{R}^{2}$ pada model pertama sebesar 0,734 atau sebesar $73,4 \%$, sedangkan sisanya $26,6 \%$ dipengaruhi oleh faktorfaktor lain yang tidak dijelaskan dalam model pertama. Pada model kedua nilai Adjusted $\mathrm{R}^{2}$ sebesar 0,807 atau sebesar $80,7 \%$, sedangkan sisanya $19,3 \%$ dipengaruhi oleh faktor-faktor lain yang tidak dijelaskan dalam model kedua. 
ISSN: 2302-8556

E-Jurnal Akuntansi Universitas Udayana

Vol.22.1. Januari (2018): 521-543

Hal ini menjadi peluang bagi penelitian selanjutnya untuk mengembangkan penelitian terkait faktor-faktor yang mempengaruhi partisipasi anggaran terhadap budgetary slack. Disarankan kepada peneliti selanjutnya agar dapat menambah variabel seperti budaya organisasi, penerapan SAP, love of money dan komitmen organisasi pada peneltian selanjutnya.

\section{REFERENSI}

Ajibolade, Omobola, dan Akinniyi, Kehinde. 2013. The Influence of Organizational Culture and Budgetary Participation on Propensity to Create Budgetary Slack in Public Sector Organizations. Journal of Arts and Social Sciences. Vol. 13 (1).

Azcarlo, Van Raalten. 2016. Pengaruh Partisipasi Anggaran, Informasi Asimetri dan Penekanan Anggaran pada Senjangan Anggaran dengan Self Esteem sebagai Variabel Moderasi. Artikel Ilmiah Universitas Jendral Soedirman. Vol. 5 (3).

Baerdemaeker, Jolien de, dan Bruggeman, Werner. 2015. The Impact of Participation in Strategic Planning on Manager's Creation of Budgetary Slack: the Mediating Role of Autonomous Motivation and Affective Organizational Commitment. Management Accounting Research. Vol. 29 (2).

Brownell, Peter. 1982. The Role of Accounting Data In Performance Evaluation, Budgetary Participative, And Organizational Effectiveness. Journal of Accounting Research. Vol. 20, Pp. 589-603.

Darlis, Edfan. 2002. Analisis Pengaruh Komitmen Organisasional dan Ketidakpastian Lingkungan Terhadap Hubungan antara Partisipasi Anggaran dengan Senjangan Anggaran. JRAI, Vol. 5 No.1.

Elmassri, Moataz, dan Harris, Ellaine. 2011. Rethinking Budgetary Slack as Budget Risk Management. Journal of Applied Accounting Research. Vol. 12 (3). Pp. 278-293.

Fahrianta, Riswan Yudhi, dan Ghozali, Imam. 2002. Pengaruh Tidak Langsung Sistem Penganggaran Terhadap Kinerja Manajerial: Motivasi Sebagai 
Variabel Intervening. Jurnal Riset Akuntansi, Manajemen dan Ekonomi. Vol. 2 (1). Pp. 77-113.

Gallani, Susanna. 2015. Budgeting, Psychological Contracts, and Budgetary Misreporting. Working Paper. Vol. 16 (17). Pp. 1-38.

Govindarajan, Vijay. 1986. Impact of Participation in the Budgetary Process on Managerial Attitudes and Performance: Universalistic and Contingency Perspective. Decision Science 17. Pp. 496-516.

Harvey, Marry Ellen. 2015. The Effect of Employee Ethical Ideology On Organizational Budget Slack: An Empirical Examination And Practical Discussion. Journal of Business \& Economics Research. Vol. 13 (1).

Hassabelnaby, Hassan R., Casey, Patricia, Douglas, dan Wier, Benson. 2013. An Investigation of the Organizational and Behavioral Effects of Corporate and National Culture on Budgeting Systems. Journal of Management Accounting. Vol. 15. Pp. 193-224.

Husain, Pratiwi. 2011. Pengaruh Partisipasi Anggaran Terhadap Senjangan Anggaran Dengan Komitmen Organisasi Sebagai Variabel Moderating. Jurnal INOVASI. Vol. 8, No 3. Universitas Negeri Gorontalo. Gorontalo.

Kramer, Stephan, dan Hartmann, Frank. 2014. How Top-down and Bottom-up Budgeting Affect Budget Slack and Performance through Social and Economic Exchange. Abacus. Vol. 50 (3). Pp. 314-340.

Lavarda, Carlos E.F. 2013. Budget Participation and Informational Asymmetry: A Study in a Multinational Company. Brazilian Business Review. Vol. 10 (2). Pp. 72-94.

Mahadewi, A.A Sg. Sinta. 2014. Pengaruh Partisipasi Penganggaran Pada Senjangan Anggaran Dengan Asimetri Informasi Dan Komitmen Organisasi Sebagai Pemoderasi. E-Jurnal Akuntansi Universitas Udayana, Vol 8 (3). Pp. 458-473. Universitas Udayana.

Novia, Putu. 2015. Pengaruh Penganggaran Partisipatif pada Budgetary Slack dengan Asimetri Informasi, Self Esteem, Locus Of Control dan Kapasitas Individu sebagai Variabel Pemoderasi. E-Journal Fakultas Ekonomi dan Bisnis UNUD. Vol.4 (5).

Otley. 1980. The Contingency Theory of Management Accounting: Achievement and Prognosis. Accounting Organization and Society. Vol. 5 (4). Pp. 413428. 
Pamungkas, Wisnu. 2014. Pengaruh Partisipasi Anggaran, Informasi Asimetri, Budaya Organisasi, Kompleksitas Tugas, Reputasi, Etika, Dan Self Esteem Terhadap Budgetary Slack. E-Journal Jurusan Akuntansi Program S1. Vol. 2 (1).

Pratama, Reno. 2013. Pengaruh Partisipasi Anggaran Terhadap Senjangan Anggaran Dengan Komitmen Organisasi Dan Motivasi Sebagai Pemoderasi. Jurnal Akuntansi. Universitas Negeri Padang. Padang.

Resen, Karma. 2014. Pengaruh Partisipasi Anggaran, Self Esteem dan Budget Emphasis terhadap Budgetary Slack Pada Hotel Berbintang Di Denpasar. E-Journal Akuntansi Universitas Udayana. Vol. 10 (1). Pp. 1-13.

Schiff, Michael, dan Lewin, Arie Y. 1970. The Impact of People on Budgets. Accounting Review. Vol. 45. Pp. 259-268.

Sinaga, Mardogan. T, 2013. Pengaruh Partisipasi Anggaran Terhadap Senjangan Anggaran Dengan Locus Of Control Dan Budaya Organisasi Sebagai Variabel Pemoderasi. E-Journal Akuntansi UNP. Vol. 1 (2).

Su, Chin-Chun, dan Ni, Feng-Yu. 2013. Budget Participation And Informational Asymmetry: A Study In A Multinational Company. International Journal of Organizational Innovation. Vol. 5 (4). Pp. 91-99.

Thien, Trinh Hiep. 2014. Factors Affecting the Propensity to Create Budgetary Slack Evidence from Vietnamese Enterprises. Journal of Economic Development. Vol. 22 (1). Pp. 100-124.

Young, Mark S. 1985. Participative Budgeting: The Effects of Risk Aversion and Asymmetric Information on Budgeting Slack. Journal of Accounting Research, Vol. 23 (2). Pp. 829-842. 